\title{
Mutagenesis in Proso Millet(Panicum miliaceum L.)
}

\author{
K. G. Bhave ${ }^{1}$, V. V. Dalvi' ${ }^{2}$ B. L. Thaware ${ }^{3}$, S. G. Mahadik ${ }^{4}$, M. C. Kasture ${ }^{5}$, S. S. Desai ${ }^{6}$ \\ Department of Agricultural Botany, College of Agriculture, Dapoli - 415712 (Maharashtra), India
}

\begin{abstract}
The dry seeds (12\% moisture) of local cultivar of proso millet viz., Vari No. 10 was irradiated with six doses of gamma rays viz., $20 \mathrm{krad}, 30 \mathrm{krad}, 40 \mathrm{krad}, 50 \mathrm{krad}, 60 \mathrm{krad}$ and $70 \mathrm{krad}$ at BARC, Trombay, Mumbai. In $M_{2}$ generation, two early maturing mutants were isolated from $40 \mathrm{krad}$ and $50 \mathrm{krad}$ doses as well as two high yielding mutants were isolated from $20 \mathrm{krad}$ and $60 \mathrm{krad}$ doses. The mutagenic treatments were effective in inducing both qualitative and quantitative characters.
\end{abstract}

Keywords: Proso millet, irradiation, variability

\section{Introduction}

Proso millet is of ancient cultivation and probably domesticated in Central and Eastern Asia, where it has been cultivated for more than 5000 years. Proso millet has long been a major crop in Northern China. Proso millet was the milium' of the Romans and the true millet of history. It was introduced into North America after the arrival of Columbus. It is occasionally grown in other parts of Europe, Asia and in North America, mainly as a source of feed for cage-birds, poultry, and as fodder to cattle.

Now-a-days, proso millet is cultivated for human consumption mainly in Eastern and Central Asia and to a lesser extent in Eastern Europe (Russia, Danube region) and from Western Asia to Pakistan and India (Bihar, Andhra Pradesh, Maharashtra etc.). In India small millet is cultivated over an area of 0.0719 million ha with total production of 0.435 million tonnes during 2012-2013 (Anonymous 2013). In Maharashtra, the largest area is found in Konkan region comprising Raigad, Thane, Sindhudurg and Ratnagiri districts. The share of proso millet of the total recorded millet trade has been estimated at about two-thirds. It is an important staple food grain in semi-arid areas where hardly any cereal crop can be grown. Proso millet is considered a potentially useful quick-maturing crop for the drier regions to fill the hunger gap before the main cereals are harvested.

This crop has high nutritional value which could be well exploited for bio-fortification of tribles, the society where maximum malnutrition and under nutrition noticed remain overlooked. Local genotypes are available but they are poor yielders having narrow genetic base and less variability. Proso millet is erect annual grass, usually free-tillering with a rather shallow root system, highly self-pollinated, has an open inflorescence and small florets with tightly held lemma and palea with cream-coloured grains and anthesis takes place during midnight. So, attempt on improvement of proso millet genotypes so far restricted to selection only, due to complicated floral biology.

Mutation breeding is tool in the hands of breeding to create variability in crop populations and to make selection in such populations with view to bring about further improvement in respective crop. It has advantage mainly in improvement of specific characteristics in well adopted and highly desirable genotypes without altering their acceptable phenotype.
Useful mutants are directly used as productive varieties as well as donor parents in hybridization programme.

The role of mutation in enlarging the genetic variability and scope for making selection in many characters like yield, earliness, number of branches, plant height, disease resistance, grain colour have been made in various crop plants.

The present research entitled - Mutagenesis in Proso Millet (Panicum miliaceum L.)" was undertaken to study the genetic variability for yield and yield components in $\mathrm{M}_{2}$ generation and to isolate of desirable mutants.

\section{Material and Methods}

\section{Material}

The proso millet genotype Vari No.10 (local collection) was taken up for the present study.

\section{Method of treatment with mutagen}

Seed of the genotype Vari No. 10 of proso millet was exposed to $20 \mathrm{krad}, 30 \mathrm{krad}, 40 \mathrm{krad}, 50 \mathrm{krad}, 60 \mathrm{krad}$ and $70 \mathrm{krad}$ of gamma rays. Dry seeds having storable moisture content i.e. 12 per cent were irradiated with gamma rays in first week of May 2013. The irradiation source used was ${ }^{60}$ Co gamma cell installed at the Biology and Agriculture Division of the Bhabha Atomic Research Centre (BARC), Trombay, Mumbai.

\section{Harvesting of $M_{1}$ plants and raising of $M_{2}$ generation} Individual plants in $\mathrm{M}_{1}$ generation were selected on the basis of their phenotypical characters and harvested separately. Besides this other panicles were also harvested for raising $\mathrm{M}_{2}$ generation. The seeds were sown on $9^{\text {th }}$ June 2014 for growing the seedlings. The seedlings were transplanted on $6^{\text {th }}$ July 2014 and $7^{\text {th }}$ July 2014. Seedlings were transplanted by plant to row progeny method. One thousand three hundred twenty five lines were transplanted comprising of all treatment including control at spacing of $30 \times 15 \mathrm{~cm}$. The recommended dose of fertilizers i.e. at the rate of $25 \mathrm{~kg}$ of $\mathrm{N}, 50 \mathrm{~kg}$ of $\mathrm{P}_{2} \mathrm{O}_{5}$ and $50 \mathrm{~kg}$ of $\mathrm{K}_{2} \mathrm{O}$ hectare ${ }^{-1}$ was applied. Observations were recorded on hundred randomly selected plants from each treatment. In $\mathrm{M}_{2}$ generation, morphological mutants were identified and harvested separately. Each observation was recorded over hundred individual plants from each treatment (mutagen dose) and the mean calculate before statistical analysis. The genetic parameters like GCV, 


\section{International Journal of Science and Research (IJSR) ISSN (Online): 2319-7064 \\ Index Copernicus Value (2013): 6.14 | Impact Factor (2014): 5.611}

PCV, heritability (h2) and genetic advance (GA) were also estimated.

\section{Results and Discussion}

In order to assess the nature and magnitude of induced polygenic variability in traits like plant height $(\mathrm{cm})$, number of productive tillers/plant, grain yield per plant (g), the different mutagenic treatment populations in $\mathbf{M}_{2}$ generation were evaluated through statistical parameters such as mean, range and genetic parameters those were estimated by methodology given by Panase and Sukhatme,1985.

\section{Plant height (cm)}

Data in regards to mean performance and genetic parameters in regards to plant height are given in table 1 . The effect of various doses of mutagen on plant height is also depicted in fig. 1.

Among all mutated population plant height was less at 50 krad $(158.22 \mathrm{~cm})$ which was appreciable. The reduction in plant height in $50 \mathrm{krad}$ and $40 \mathrm{krad}$ indicates negative shift from the mean while other doses increased height show positive shift. Regarding plant height negative shift is desirable to obtain semi dwarf and intermediated types. The dwarf individuals in the population need to be isolated for identifying plants with reduced height. Highest genotypic variance and heritability recorded by 40 krad dose. This was in supports with finding of Hayat et al. (1990) in sorghum, Mehta and Dhagat (1994) in ragi, Singh and Balyan (2009) in bread wheat and Nirmalakumari et al. (2007) in little millet.

\section{Number of productive tillers per plant}

Data in regards to mean performance and genetic parameters in regards to number of productive tillers are given in table 2. The effect of various doses of mutagen on plant height is also depicted in fig. 2 .

Irradiation caused significant variation in productive tillers per plant. In general, irradiation treatment caused noticeable increase in number of tillers per plant. The maximum number of tillers were present at 20 krad (5.99) treated population. The genotypic variance, $\mathrm{h}^{2}$ and GA were highest at 50 krad dose. This was confirmed by Mehta and Dhagat (1994) in ragi, Nirmalakumari et al. (2007) in little millet and Chakravarti et al. (2013) in rice.

\section{Grain yield per plant (g)}

Data in regards to mean performance and genetic parameters in regards to grain yield per plant are given in table 3 . The effect of various doses of mutagen on plant height is also depicted in fig. 2 .

Highest mean for grain yield per plant was observed at 20 krad (16.49 g) among irradiated population than control (10.15 g). The genotypic variance, $h^{2}$ and GA were also highest at 20 krad dose. Variation with respect to grain yield was observed by Hayat et al. (1990) and Human et al. (2007) in sorghum, Nirmalakumari et al. (2007) in little millet, Rahimi and Bahrani (2011) in wheat and Chakravarti et al. (2013) in rice.

Table 1: Mean, Range and Genetic parameters for plant height (cm) in $M_{2}$ generation

\begin{tabular}{|l|l|l|l|l|l|l|l|l|l|}
\hline Treatment & Mean & Range & Vg & Vp & PCV & $\mathbf{G C V}$ & $\mathbf{h}^{2}{ }_{(\mathbf{b s})}$ & GA & GAM \\
\hline $\mathbf{2 0}$ krad & 185.7 & $145-218$ & 167.97 & 269.79 & 8.84 & 6.97 & 62.25 & 21.07 & 11.34 \\
\hline $\mathbf{3 0}$ krad & 181.76 & $160-203$ & 83.24 & 185.06 & 7.48 & 5.01 & 44.98 & 12.61 & 6.94 \\
\hline $\mathbf{4 0}$ krad & 164.3 & $120-210$ & 433.27 & 535.09 & 14.07 & 12.66 & 80.97 & 38.58 & 23.48 \\
\hline $\mathbf{5 0}$ krad & 158.22 & $129-182$ & 117.35 & 219.17 & 9.35 & 6.84 & 53.54 & 16.33 & 10.32 \\
\hline $\mathbf{6 0}$ krad & 172.1 & $146-193$ & 106.51 & 208.33 & 8.38 & 5.99 & 51.12 & 15.20 & 8.83 \\
\hline 70 krad & 169.85 & $138-197$ & 155.84 & 257.66 & 9.45 & 7.34 & 60.48 & 20.00 & 11.78 \\
\hline Control & 168.58 & $143-225$ & 101.82 & 203.64 & 8.46 & 5.98 & 50 & 14.70 & 8.72 \\
\hline
\end{tabular}

Table 2: Mean, Range and Genetic parameters for number of productive tillers in $\mathrm{M}_{2}$ generation

\begin{tabular}{|l|l|l|l|l|l|l|l|l|l|}
\hline Treatment & Mean & Range & Vg & Vp & PCV & GCV & $\mathbf{h}^{2}$ (bs) & GA & GAM \\
\hline 20 krad & 5.99 & $4-14$ & 2.72 & 3.39 & 30.73 & 27.58 & 80.52 & 3.05 & 50.99 \\
\hline $\mathbf{3 0}$ krad & 3.28 & $1-7$ & 1.14 & 1.8 & 40.92 & 32.57 & 63.35 & 1.75 & 53.41 \\
\hline 40 krad & 3.6 & $1-8$ & 1.96 & 2.62 & 44.96 & 38.88 & 74.8 & 2.49 & 69.29 \\
\hline $\mathbf{5 0}$ krad & 3.38 & $1-10$ & 2.99 & 3.65 & 56.56 & 51.2 & 81.94 & 3.23 & 95.49 \\
\hline 60 krad & 4.21 & $1-8$ & 2.14 & 2.8 & 39.78 & 34.79 & 76.47 & 2.64 & 62.68 \\
\hline 70 krad & 2.99 & $1-7$ & 1.44 & 2.11 & 48.58 & 40.27 & 68.71 & 2.06 & 68.77 \\
\hline Control & 2.86 & $1-6$ & 0.66 & 1.32 & 40.17 & 28.41 & 50 & 1.18 & 41.38 \\
\hline
\end{tabular}

Table 3: Mean, Range and Genetic parameters for grain yield per plant (g) in $\mathrm{M}_{2}$ generation

\begin{tabular}{|l|l|l|l|l|l|l|l|l|l|}
\hline Treatment & Mean & Range & Vg & Vp & PCV & GCV & $\mathbf{h}^{2}{ }_{(\text {bs) }}$ & GA & GAM \\
\hline 20 krad & 16.49 & $4.85-49.26$ & 57.21 & 65.94 & 49.23 & 45.85 & 86.76 & 14.51 & 87.99 \\
\hline 30 krad & 9.98 & $3.77-26.33$ & 20.25 & 28.98 & 53.93 & 45.08 & 69.88 & 7.75 & 77.65 \\
\hline $\mathbf{4 0}$ krad & 10.6 & $0.01-29.16$ & 35.45 & 44.18 & 62.69 & 56.16 & 80.24 & 10.99 & 103.64 \\
\hline $\mathbf{5 0}$ krad & 7.59 & $0.47-20.67$ & 16.15 & 24.87 & 65.65 & 52.89 & 64.91 & 6.67 & 87.79 \\
\hline 60 krad & 12.48 & $4.07-34.55$ & 39.86 & 48.59 & 55.85 & 50.58 & 82.03 & 11.78 & 94.39 \\
\hline 70 krad & 7.54 & $0.74-21.06$ & 18.87 & 27.59 & 69.6 & 57.55 & 68.37 & 7.40 & 98.04 \\
\hline Control & 10.1582 & $3.95-23.45$ & 8.72 & 17.45 & 41.13 & 29.08 & 50 & 4.30 & 42.37 \\
\hline
\end{tabular}




\section{International Journal of Science and Research (IJSR) \\ ISSN (Online): 2319-7064}

Index Copernicus Value (2013): 6.14 | Impact Factor (2014): 5.611

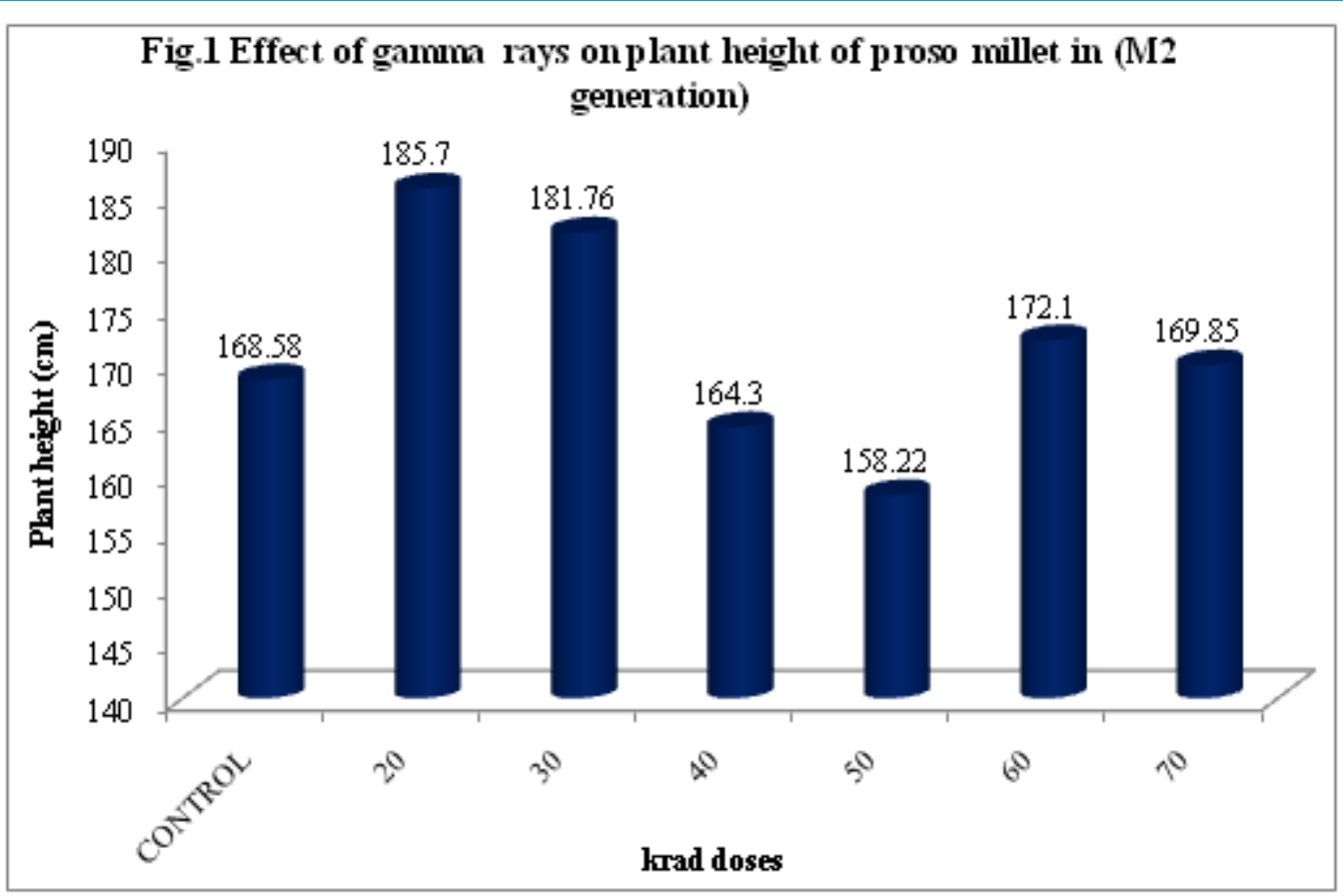

Fig.2 Effect of gamma rays on no.of productive tillers and grain yield per plant of proso millet (M2 generation)

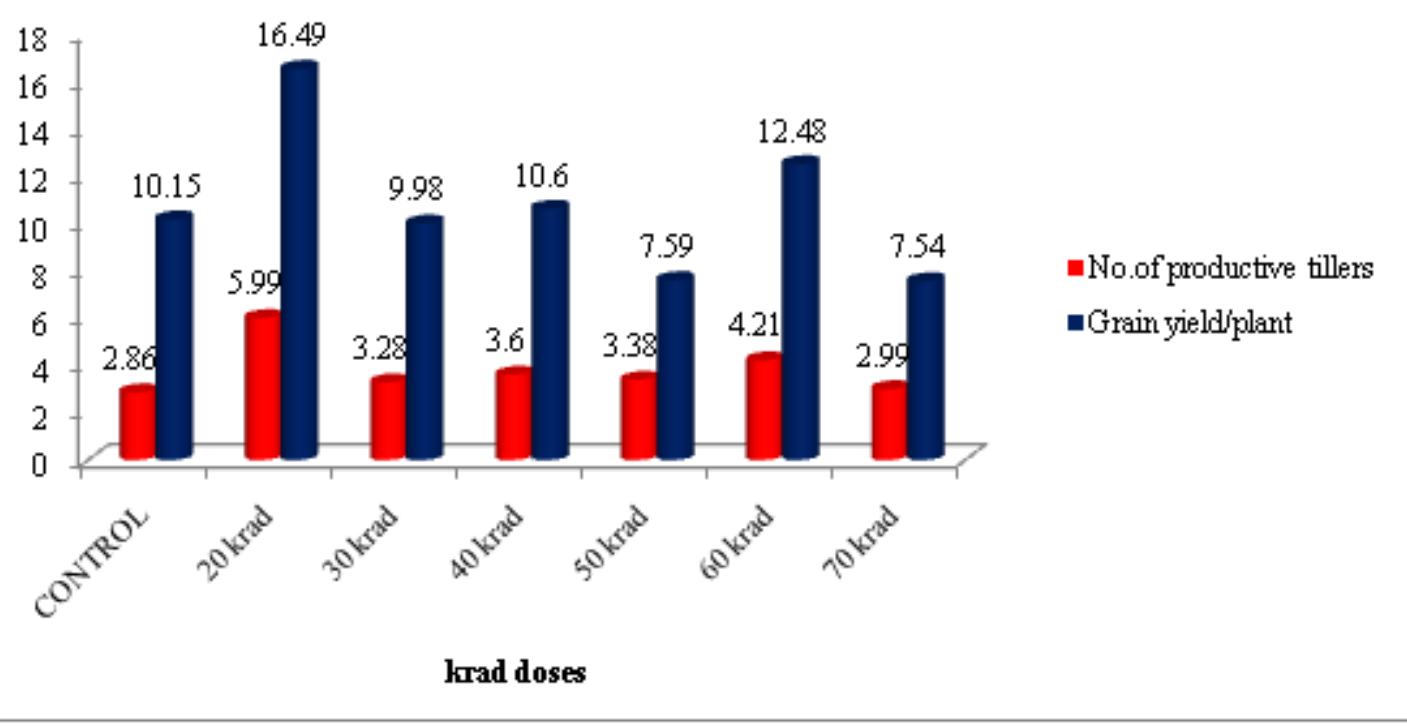

The different gamma irradiated doses created the various morphological mutants in $\mathbf{M}_{2}$ population. Among them fourteen mutants were selected. The dwarf mutants were selected those showed the height of $120 \mathrm{~cm}$ and $129 \mathrm{~cm}$ as compared to control ( unirradiated) dwarfest plant $143 \mathrm{~cm}$ observed in the population. As well as two high yielding mutants were selected on the basis of more grain yield per plant i.e. $49.26 \mathrm{~g}$ and $34.55 \mathrm{~g}$ as compared to control 23.45 g. The details of these selected desirable mutants are given in table 4.
Table 4: List of isolated mutants

\begin{tabular}{|l|c|c|}
\hline \multicolumn{1}{|c|}{ I } & Pedigree & Particulars/Purpose \\
\hline 1. & $20 k r a d-21-1$ & High yielding \\
\hline 2. & $20 \mathrm{krad}-85-8$ & Fodder purpose \\
\hline 3. & $20 \mathrm{krad}-224-12$ & Fodder purpose \\
\hline 4. & $30 \mathrm{krad}-146-16$ & Synchronized maturity \\
\hline 5. & $30 \mathrm{krad}-183-1$ & Synchronized maturity \\
\hline 6. & $40 \mathrm{krad}-192-2$ & Compact panicle like sorghum \\
\hline 7. & $40 \mathrm{krad}-194-9$ & Dwarfness \\
\hline 8. & $50 \mathrm{krad}-97-5$ & $\begin{array}{c}\text { Black colour seeds \& compact panicle } \\
\text { like sorghum }\end{array}$ \\
\hline 9. & $50 \mathrm{krad}-177-14$ & Purple panicle \\
\hline 10. & $50 \mathrm{krad}-177-15$ & Purple panicle \\
\hline 11. & $50 \mathrm{krad}-156-6$ & Dwarfness \\
\hline 12. & $60 \mathrm{krad}-101-19$ & High yielding \\
\hline 13. & $60 \mathrm{krad}-118-2$ & Compact panicle like sorghum \\
\hline 14. & $70 \mathrm{krad}-53-12$ & Fodder type \& synchronized maturity \\
\hline
\end{tabular}




\section{Conclusion}

Variability can be created through gamma rays irradiation technique. $20 \mathrm{KR}$ gamma rays dose was found to be most effective dose for creating variability in prosomillet.The local cultivar Vari No. 10 responded more and more number of viable and economic mutants for higher productivity observed at 20 krad than any other mutagenic treatments. The present investigation revealed that, the isolation of mutants with high yield and yield component character is possible in $20 \mathrm{krad}$ dose of gamma irradiation in proso millet. Isolated mutants will be confirmed by growing next generation. Superior mutants may be directly used in plant breeding system.

\section{References}

[1] Anonymous 2013.Economic Survey of Maharashtra.Government of Maharashtra.

[2] Chakravarti, K.R., Singh S., Kumar H., Lal J.P., and Vishakarma M.K. 2013.Study of induced polygenic variability in $\mathrm{M}_{1}$ and chlorophyll mutations in $\mathrm{M}_{2}$ generations in aromatic rice.The Bioscan,8(1): 49-53.

[3] Hayat, K., Khan A., Sadiq M., Elahi F. and Shakoor A. 1990.Gamma radiation induced variation in sorghum cultivars. Pakistan J. Agri. Res., 11(1):13-16.

[4] Mehta, A. K. and Dhagat N. K. 1994.Induced mutation in ragi (Eleuisinecoracana G.).Advances in Plant Sciences; 7(2);292-294.

[5] Nirmalakumari, A., Arulselvi S., Ganapathy S., Souframanian J., Senthil N. and Devan P. 2007. Gamma ray induced variation for lodging resistance and its associated characters in little millet (Panicum sumatrense Roth Ex-roem and schult). Madras Agric. J., 94(712):151-155.

[6] Panse, V.G. and P.V. Sukhatme (1985). Statistical methods for Agriculture workers. ICAR, New Delhi.

[7] Rahimi, M. M. and Bahrani A. 2011. Influence of gamma radiation on some physiological characteristics and grain protein in wheat (Triticumaestivum). World Appl. Sci. J., 15(5):654-659.

[8] Singh, N.K. and Balyan H.S. 2009.Induced Mutations in Bread wheat (TriticumaestivumL.)Cv. Kharchia $65^{\circ}$ for reduced plant height and improve grain quality traits. Advances in Bio. Res. 3(5-6):215-221. 